\title{
Zuzanna Kruk-Buchowska
}

zuzana@amu.edu.pl

Wydział Anglistyki

Uniwersytet im. Adama Mickiewicza w Poznaniu

ORCID: 0000-0002-5783-8483

\section{THE CONTINUOUS STRUGGLE FOR LAND AND SOVEREIGNTY - THE CASE OF THE MASHPEE TRIBE}

\author{
Niekończąca się walka o ziemię i suwerenność - \\ przypadek plemienia Mashpee
}

\begin{abstract}
The article analyzes the Mashpee Wampanoag Nation's fight for recognition as a tribe and the recent attempts by the US federal government to take their land out of trust. Mashpee's 1977-1978 lost court case was famously described by James Clifford in a chapter of his book, The Predicament of Culture (1988). The text looks at the continuation of their legal struggle, their recognition as a tribe under the Code of Federal Regulations in 2007 and their recent legal battle to keep their lands. Mashpee's case is illustrative of the changes in the general perspective of tribal nations' identities and histories which have taken place in the United States since the 1970s, as reflected in the legal documents analyzed. It also shows that the change in perspective and law itself does not necessarily guarantee sovereignty to tribal nations. Thus, the article takes a legal anthropological approach to the issue of their subjectivity and legal status.
\end{abstract}

Key words: Mashpee Wampanoag Nation, tribal sovereignty, Indigenous land rights, Indigenous identity

Streszczenie: Artykuł analizuje walkę narodu Mashpee Wampanoag o uznanie go jako plemienia przez państwo oraz ostatnie prób rządu federalnego USA, aby odebrać im ziemię. Sprawa sądowa Mashpee z lat 1977- 
1978, którą przegrali, została opisana przez Jamesa Clifforda w jednym z rozdziałów jego znanej książki The Predicament of Culture (1988; wyd. polskie Kłopoty z kultura 2000). W tekście tym omówiona jest dalsza walka prawna o rzeczone uznanie ich za plemię przez rząd federalny w 2007 roku zgodnie z Kodeksem Przepisów Federalnych, oraz trwająca batalia prawna o zachowanie swoich ziem. Przypadek plemienia Mashpee obrazuje zmianę $\mathrm{w}$ postrzeganiu tożsamości i historii narodów plemiennych, jaka zaszła w USA od końca lat siedemdziesiątych XX wieku. Znajduje ona swoje odzwierciedlenie $\mathrm{w}$ analizowanych dokumentach prawnych. Artykuł pokazuje również, że same transformacje w postrzeganiu tożsamości i wynikające $\mathrm{z}$ nich zmiany prawne niekoniecznie gwarantują suwerenność rdzennych narodów. Zatem przedsięwzięcie to podchodzi do zagadnienia podmiotowości i statusu prawnego tych grup z perspektywy antropologii prawa.

Słowa kluczowe: plemię Mashpee Wampanoag, suwerenność plemienna, prawa do ziemi rdzennej ludności, tożsamość rdzennej ludności

\section{Introduction}

On Saturday, March 27, 2020, Cedric D. Cromwell, president and chairman of the Mashpee Wampanoag Tribe announced that it would lose its reservation status by order of the US Secretary of the Interior, as the Department of the Interior (DOI) would be taking their land out of trust. The announcement came after a phone call from the DOI on the previous day. "For the first time since the termination era, the Department of the Interior (DOI) attempted to disestablish a Tribal reservation, ordering the homelands of the Mashpee Wampanoag Tribe to be taken out of trust" (Mashpee Wampanoag Tribe 2020a).

The tribe is located in the town of Mashpee, on Cape Cod in the state of Massachusetts, in the New England region of the United States. As tribes are sovereign nations under U.S. law, they are only subject to federal laws and regulations. When land is brought into trust by federal government, special protections and privileges are granted to the land and tribe; as a result, the land cannot be taken away from it or sold to a non-Native without the government's approval, and it is not subject to state or local laws and taxes (Cannon and McDougall 2020). 
The continuous struggle for land...

The decision was brought to the tribe amidst a state of emergency forthe Mashpee Wampanoag nation, which was declared in response to the Covid-19 pandemic, and during which time the tribal council was trying to gather the resources needed to deal with the crisis (Cannon and McDougall 2020). It was met with an immediate legal reaction from the tribe - it asked the Court to issue an emergency restraining order to prevent DOI from taking immediate action to disestablish its reservation (Mashpee Wampanoag Tribe 2020a) - and protest and support from Native American institutions, such as, the National Congress of American Indians and the United South and Eastern Tribes Sovereignty Protection Fund (USET SPF). ${ }^{1}$ The case was also widely covered in Native American media outlets, such as Indian Country Today, and local and national newspapers, e.g. the Boston Globe and Time. In social media, the hashtag \#IstandwithMashpee spread quickly. Many of those who had learned of the news expressed surprise and disbelief, and scorned the government for making a decision with such devastating consequences for the tribe, particularly during such a trying time. President Cromwell said that although it was painful to hear the news, he was not surprised (Jungreis 2020). He declared the tribe would keep fighting for sovereignty over its ancestral lands and stated: "We will not rest until we are treated equally with other federally recognized tribes and the status of our reservation is confirmed" (Jungreis 2020).

Indeed, DOI's decision was just one setback in Mashpee's long fight for federal recognition as a tribe, and the following efforts to acquire tribal lands and defend its sovereignty. The purpose of this article is to analyze their struggle and its legal complexities, with an emphasis on the cultural and political underpinnings of the definitions of "Indian" and "tribe", together with the criteria for recognition that the Mashpee have had to meet throughout the process. They reflect the prevailing perspectives of Indigenous identity, history and sovereignty at the different periods described, which often vary substantially from Indigenous perspectives. Both the changes in these understandings and continuing ideas will be underscored, which will hopefully help explain why, after almost half-a-century since the start of their legal battle, the Mashpee Wampanoag Nation still has to keep warding off attempts at stripping it of its lands and sovereignty.

${ }^{1}$ I will be referring to Indigenous peoples of the United States collectively as Native Americans, Indigenous communities/peoples, or tribal nations and Native American tribes. I will only use the terms "Indian" or "American Indian" when referring to specific legal documents that use those terms. 
The article will focus on three events in the tribe's battle for sovereignty: (1) the 1977-1978 legal dispute Mashpee Tribe v. New Seabury et al. for possession of land, which ended up being a case of the Mashpee proving their identity as a tribe (described by anthropologist James Clifford in a chapter of his book The Predicament of Culture (1988), which the relevant section of this article is based on); (2) the tribe's 1990 petition to the Bureau of Indian Affairs to gain federal recognition, which ended in Mashpee Wampanoag Nation's success, albeit only in 2008; and (3) the recent DOI decision to strip the tribe of its land, the following Washington D.C. circuit court decision reverting that of DOI, and the congressional support the Mashpee have garnered.

\section{Mashpee Tribe v. New Seabury et al.}

In August 1976, the Mashpee Wampanoag Tribal Council, Inc. sued in U.S. District Court in Boston for possession of land constituting about three-quarters of the town of Mashpee, "Cape Cod's Indian Town". The purpose of the trial, however, shifted from settling the question of ownership to determining whether the group was in fact a Native American tribe, and the same tribe that in the mid-nineteenth century had lost its lands through a series of disputed legislative acts (Mass Moments 2008).

The basis for their claim was the Non-Intercourse Act of 1790, according to which alienation of Native American lands could be carried out only with the permission of Congress. After court decisions confirmed that the Act also applied to non-reservation Native Americans (i.e., groups that did not have a designated reservation), the way was open for suits like those of the Maine tribes, claiming that all American Indian land transfers, including ordinary purchases, were invalid, since they had been made without Congress's permission (Clifford 1988: 278).

However, the distinctiveness of the Mashpee tribe was not so obvious. The reasons for this were the following: their institutions of tribal governance had been elusive, especially during the 150 years preceding the suit; since around 1800 the Massachusett language had no longer been commonly spoken in Mashpee; the public religion in the town was at first mostly Presbyterian, then Baptist; over the centuries, inhabitants had intermarried with other Native American groups, whites, blacks, Hessian deserters from the British Army during the Revolutionary War and Cape 
The continuous struggle for land...

Verde Islanders; and the inhabitants of Mashpee were active in the economy and society of modern Massachusetts (Clifford 1988: 278). The Boston jury had to answer the question, whether this group of people, of Native American ancestry could file suit as the Mashpee tribe that, as they claimed, had been despoiled of collectively held lands during the mid-nineteenth century (Clifford 1988: 278). This was a prerequisite for the matter to proceed to a land-claim trial.

The Mashpee Tribe v. New Seabury et al. dispute began in the late fall of 1977 and lasted forty-one days. Mashpee Tribe stood for the plaintiffs, the Mashpee Wampanoag Tribal Council, Inc., described by the group as the legal arm of the Mashpee Tribe. The suit was prepared by lawyers from the Native American Rights Fund, a non-profit advocacy group. New Seabury et al. referred to the New Seabury Corporation (a large development company), the Town of Mashpee (representing over a hundred individual landowners), and various other classes of defendants (insurance companies, businesses, property owners).

In 1869 the community living in Mashpee was accorded formal township status. From 1869 until 1964 the Wampanoag represented most of the town's year-round population, and maintained political control of the town ("Mashpee Wampanoag: A history" 2002). In these years every selectman but one was Native American or married to a Native American and the families of town officers were closely interrelated. "No one contested the fact that before the 1960s Mashpee was governed by Native Americans. The disagreement was over whether they governed as an 'Indian tribe"" (Clifford 1988: 279).

In the 1950s and 1960s Mashpee became popular as a place for retirement, vacation, condominiums, and luxury developments. The income of money was first received enthusiastically by many of the town's Indigenous residents. However, when local government passed out of their control, and as the scale of the development grew, a lot of the Wampanoag began to feel threatened (Clifford 1988: 280). Moreover, as many of the open spaces were turned into subdivisions, the Wampanoag's long-free movement through the large tracts of undeveloped woodlands for hunting and to the waters for fishing was impeded (Mass Moments 2008). In addition, run-off from the development of houses and malls forced the closing of their traditional shell fishing grounds. Especially the New Seabury development, on a stretch of coastline and with its expansionist plans, seemed particularly egregious. Tensions between traditional residents and 
newcomers increased, finally leading to the suit, which was filed with the support of the majority, but not all, of the Native Americans in Mashpee. Although the land claim focused on a loss of property in the nineteenth century, it was in fact "an attempt to regain control of a town that had slipped from Native American hands very recently" (Clifford 1988: 280).

However, Mashpee's tribal identity was challenged. Apart from the fifty-five acres of land acquired just before the trial, the Native Americans in Mashpee owned no tribal lands. What is more, they had no surviving language, no distinct religion, no manifest political structure, and no strong kinship. Yet, they did have a place and reputation - Mashpee had been known as an "Indian town" for centuries (Clifford 1988: 289). The boundaries of the town had not changed since 1665, when the land was given to a group called the South Sea Indians by the neighboring leaders Tookonchasun and Weepquish. Surviving pieces of Indigenous tradition and political structures that seemed to have come and gone were also present, and so was a sporadic history of Indigenous revival continuing into the present.

In the course of their litigation, certain underlying structures governing the recognition of identity and difference became visible: looked at one way, they were Native American, seen another way, they were not (Clifford 1988: 289). The trial was not as much a search for the facts of Mashpee Indigenous culture and history as it was "an experiment in translation", part of a long historical conflict and negotiation of "Native American" and "American" identities (Clifford 1988: 289).

The issues disputed by the two sides during the trial were the following: the creation of the "South Sea Indian Plantation" in 1685; conversion to Christianity of the American Indians in Mashpee; Mashpee's plantation status; fighting on the colonists' side during King Phillip's War in 1675 and during the Revolutionary War; intermarriage; obtaining township status in 1870; and Mashpee's tribal activity during the period of assimilation.

The defendants' point of view was clear: there never had been a Native American tribe in Mashpee. Encounter with the colonists created a community which consisted of a collection of different Native Americans and other minorities, who gradually sought to become full citizens of the Commonwealth of Massachusetts and of the United States. Decimated by disease, converted to Christianity, wanting freedom from paternalistic state tutelage, the people of mixed Native American descent in Mashpee 
The continuous struggle for land...

gradually assimilated into American society and their Native identity had been progressively lost since the mid-nineteenth century (Clifford 1988: 294).

Drawing on the same documentary record, the plaintiffs came up with a different story. In their account the residents of Mashpee had managed to keep alive a core of Native American identity over three centuries against great odds. They achieved this by being flexible, sometimes even surreptitious, always trying to control, not reject, outside influences (Clifford 1988: 302).

To the defendants' mind, the new sense of being Native American around Mashpee was a matter of county fair-like powwows, costumes, and folkloric dances. They claimed the individuals of Native American ancestry from Mashpee who filed suit in 1976 were American citizens similar to Irish- or Italian-Americans with strong ethnic attachments. They had simply taken advantage of the latest wave of pan-American Indian revivalism and the prospect of financial gain to constitute themselves as a Mashpee tribe. They felt that Mashpee's distinctive history was in fact a story of American Indian-Christian remnants who over the centuries had repeatedly given up their customs and sovereignty. Theirs had been a long, hard struggle for equality and respect in multiethnic America (Clifford 1988: 301).

The plaintiffs, on the other hand, asserted that the Mashpee Native Americans did not assimilate, and that the term's linear, either-or connotations cannot account for revivalism and for changes in the cultural and political climate between 1869 and 1960 (Clifford 1988: 309). The late nineteenth and early twentieth centuries were among the worst periods for Native Americans. During this period, government policy strongly favored tribal termination and the dispersal of collective lands. Thus, it should be no surprise that there is little evidence in the historical record of tribal life in Mashpee between 1869 and 1920. A lot of the groups that would emerge later as tribes kept a low profile during these years. Mashpee seemed to be simply a sleepy town run by Native Americans, known for its good hunting and fishing (Clifford 1988: 309).

The Mashpee have survived as Indigenous peoples because they have not conformed to white stereotypes. Since aboriginal times they have lived in a traditional locale. They have maintained their own hybrid faith. They have controlled the rate of intermarriage and have fought for the autonomy of their community. Explicit tribal political structures have some- 
times been visible to the outside world, however, most of the time, they have been informal and often, the tribe in Mashpee was simply people deciding things by consensus (Clifford 1988: 309-310). The chief in Mashpee, if there was one, shared authority with a variety of respected leaders, women and men. Politics was not hierarchical and did not need much in the way of institutional forms. The tribe in Mashpee was simply shared Native American kinship, place, history, and a long struggle for integrity without isolation. Sometimes, the Baptist parish served as an arm of the tribe; so did the town government. When the Mashpee Wampanoag Tribal Council, Inc. filed suit in 1976, it did so as a new legal arm of the tribe (Clifford 1988: 309-310).

Expert testimony by professional anthropologists and historians played a substantial role in the Mashpee trial (Clifford 1988: 317). The defense relied mostly on the historical testimony of one scholar, while the plaintiffs depended more on anthropologists.

The main expert witnesses were, for the plaintiffs, James Axtell, a well-known ethno-historian, and Jack Campisi, an anthropologist who had researched the Oneida of New York State (Clifford 1988: 317). They were seconded by William Sturtevant of the Smithsonian Institution and the Sioux scholar activist Vine Deloria. The defense relied on a sociologist, Jean Guillemin, who had researched the Micmac in Boston, and Francis Hutchins, a historian (Clifford 1988: 318). The defense built its case on historical research, presenting a complete documentary record of Mashpee history.

The jury was asked whether the proprietors of Mashpee were an American Indian tribe on six dates relevant to the land claim suit: (1) July 22, 1790, the date of the enactment of the first Federal Non-Intercourse Act; (2) March 31, 1834, the date on which the District of Mashpee was established; (3) March 3, 1842, when land was partitioned among the proprietors of Mashpee and their children; (4) June 23, 1869, the end of all alienation restraints; (5) May 28, 1870, incorporation of the Town of Mashpee; and (6) August 26, 1976, commencement of the present suit (Mashpee Tribe, Plaintiff, Appellant, v. New Seabury Corp. et al. 1979).

The jurors were also asked to decide on a seventh question: Did a tribe in Mashpee exist continuously during the relevant historical period? (Mashpee Tribe, Plaintiff, Appellant, v. New Seabury Corp. et al. 1979). If not, the plaintiffs would fail. Furthermore, the jurors were instructed that if at any time they found tribal status in Mashpee to have been voluntarily abandoned, then it could not be revived. 
The continuous struggle for land...

The judge gave the legal definition of tribe that would apply. He opted for a relatively loose formula preferred by the plaintiffs and drawn from the case of Montoya v. United States, 1901: "A body of Indians of the same or similar race united in a community under one leadership or government and inhabiting a particular, though sometimes ill defined, territory" (Montoya v. United States 1901). For the plaintiffs to win, all the key factors of race, territory, community, and leadership had to be continuously present.

In their verdict, the jury answered 'no' to all but two of the seven questions (questions no. 2 and 3) (Mashpee Tribe, Plaintiff, Appellant, v. New Seabury Corp. et al. 1979). Clearly, the verdict was a setback for Mashpee's suit. Nonetheless, as a statement about their tribal history, it was far from clear. After hearing arguments, the judge finally decided that despite its ambiguity - the apparent emergence of a tribe in 1834-the jury's answer was a denial of the required tribal continuity.

\section{Interpretation of the verdict}

In analyzing the verdict, James Clifford writes:

In Boston Federal Court, Cape Cod Indians could not be seen for what they were and are. Modern Native American lives_-lived within and against dominant culture and state-were not captured by categories like tribe or identity. The plaintiffs could not prevail in court because their discourse and that of their attorneys and experts was inevitably compromised. It was constrained not simply by the law, with its peculiar rules, but by powerful assumptions and categories underlying the common sense that supported the law (Clifford 1988: 336-337).

He goes on to explore those underlying assumptions and categories: the idea that culture carries with it an expectation of roots, of a stable, territorialized existence, as reflected in the Montoya definition of tribe, and the continuity of history and identity, implicit in the court's either-or logic, i.e., the expectation that the plaintiffs' identity be demonstrated as an uninterrupted narrative, either of survival or change, ruling out the possibility of a group existing discontinuously, keeping open multiple paths, being simultaneously Indigenous and American (Clifford 1988: 338-341).

He also points to the fact that institutions of culture and tribe are historical inventions, and that Mashpee's history is "a long, relational struggle 
to maintain and recreate identities" that began when the Mashpee first came into contact with the white settlers at Plymouth (Clifford 1988: 339). It has in fact been a history of 'survivance', to use Gerald Vizenor's term (Vizenor 1994). Clifford notes:

Until recently, the 'history' accorded to tribal peoples has always been a Western history. They may refuse it, embrace it, be devastated by it, changed by it. But the familiar paths of tribal death, survival, assimilation, or resistance do not catch the specific ambivalences of life in places like Mashpee over four centuries of defeat, renewal, political negotiation, and cultural innovation (Clifford 1988: 342).

I would add to this poignant observation that the reason behind such an interpretation of Indigeneity, history and culture, as represented by the jury and the defendants' narrative in the trial, has also been keeping land out of Mashpee's hands and denying them sovereignty, in other words, maintaining the (post)colonial status quo. In my view, the trial was not only an "experiment in translation" (Clifford 1988: 289), as the author put it, between two perspectives of history - a Western and an Indigenous one - but also an instance of the jury not recognizing Mashpee's perspective, so that the Seabury Corporation and non-Indigenous community in Mashpee could remain in control of the land and benefit from it financially.

Despite the trial's outcome, tribal life had once again become powerful in Mashpee. The Tribal Council, however, did not rest its case after the initial failure. In 1979, it appealed the ruling to the First Circuit Court of Appeals, but the judge upheld the previous verdict. Later that year, it attempted to make yet another appeal, to the U.S. Supreme Court which, however, declined to hear the case.

At the same time, a new legal pathway opened up for the Mashpee. In the years immediately following the verdict, the Bureau of Indian Affairs (BIA) standardized its procedures for recognition claims in the Code of Federal Regulations. ${ }^{2}$ A petition filed by Mashpee's fellow Wampanoags at Gay Head was turned down in a preliminary finding in 1986. Howe-

${ }^{2}$ Bureau of Indian Affairs (BIA) "is the oldest agency of the United States Department of the Interior. Established in 1824, it is responsible for the administration and management of 55 million surface acres and 57 million acres of subsurface minerals estates held in trust by the United States for American Indian, Indian tribes, and Alaska Natives. Their missions is to: "... enhance the quality of life, to promote economic opportunity, and to carry out the responsibility to protect and improve the trust assets of American Indians, Indian tribes, and Alaska Natives" (www.bia.gov/about -us). 
ver, in February 1987, for the first time ever, the Bureau of Indian Affairs reversed a negative preliminary finding, and the Gay Head Wampanoags were given full tribal recognition. In 1990, the Mashpee submitted their own petition to the BIA. In 2005, they were finally promised to have their bid for recognition decided by early 2007. An analysis of the new criteria used in the Code of Federal Regulation allows one to see how the concepts of culture, history and identity have changed in the law after the 1977-1978 trial. It is important to note that these new regulations have been introduced after the period of self-determination was introduced in federal policy toward Native Americans, and the general attitude toward Indigenous sovereignty had changed in American society as a result of Indigenous activism during the Native American Civil Rights Movement.

\section{Meeting the seven criteria of federal recognition (1990-2007)}

On February $15^{\text {th }}, 2007$, the BIA finally recognized the Mashpee Wampanoag as a tribe. The long-awaited decision entitled it to a government-to-government relationship with the United States, thus opening new legal and financial opportunities for the Mashpee. In order to be entitled to such a political relationship, the Mashpee had to meet all seven mandatory criteria set forth in Part 83 of Title 25 of the Code of Federal Regulations, Procedures for Establishing that an American Indian Group Exists as an Indian Tribe:

1. The petitioner has been identified as an American Indian entity on a substantially continuous basis since 1900 .

2. A predominant portion of the petitioning group comprises a distinct community and has existed as a community from historical times until the present.

3. The petitioner has maintained political influence or authority over its members as an autonomous entity from historical times until the present.

4. A copy of the group's present governing document including its membership criteria. In the absence of a written document, the petitioner must provide a statement describing in full its membership criteria and current governing procedures.

5. The petitioner's membership consists of individuals who descend from a historical Indian tribe or from historical Indian tribes which combined and functioned as a single autonomous political entity. 
6. The membership of the petitioning group is composed principally of persons who are not members of any acknowledged North American Indian tribe.

7. Neither the petitioner nor its members are the subject of congressional legislation that has expressly terminated or forbidden the Federal relationship (Bureau of Indian Affairs 1994). ${ }^{3}$

When the Mashpee litigated its land claim suit in 1977-1978, the Federal Government did not participate as a party, nor was it bound by the decision. At the time of the trial, the federal acknowledgement regulations had not been promulgated in their final form. Therefore, the DOI reserved the right to determine whether the Mashpee constituted an Indian tribe within the meaning of the regulations issued by the Department in 1978.

Before the final determination was issued, on March 31 st 2006 , the petition received preliminary approval; however, the Massachusetts Attorney General, David Kerrigan, questioned some of conclusions in the proposed finding (PF) (Bureau of Indian Affairs 2007: 12). He claimed that the defendants' testimonies from the 1977-1978 trial record were not given enough consideration. The issues under question regarded tribal continuity and political authority (the second and third criterion).

The Mashpee countered that the testimony and opinions were fully examined and that apart from this, they were based on vastly different standards.

Without the benefit of regulations defining the federal-tribal relationship Dr. Guillemin and Mr. Hutchins employed standards that reflect an archaic, anachronistic view of what an Indian tribe is. According to their definitions, tribes are geographically and culturally isolated; their members do not participate in the larger market economy or in state and federal political activities, and they have minimal interaction with non-members. Such an outdated definition completely fails to capture the reality of hundreds of tribes today, most of which live and interact with non-Indians, rely on federal funding to support culturally-specific education and language preservation, focus on modern economic development partnerships in order to support - not contradict - their sovereignty, and have members who participate in state and federal politics. In short, there is nothing

\footnotetext{
${ }^{3}$ Please note that these procedures have been further revised since Mashpee's 2007 acknowledgement process. However, these further changes do not fall under the scope of this article.
} 
in the cited transcript pages that contradicts or is inconsistent with the present detailed findings and conclusions in the Proposed Finding. Bureau of Indian Affairs 2007: 12-13)

The BIA reevaluated its findings, and the Attorney General's concerns were eventually dismissed (Bureau of Indian Affairs 2007: 14). Still, the reevaluation clearly shows the differences between the recognition criteria used during the 1977-1978 trial, and those used in the federal acknowledgement process. I will analyze them below, in order to show how ideas underlying the criteria of continuity of community and political authority with regard to Native American tribes have changed in the law since the trial.

\section{Contesting community continuity (criterion 2)}

Some of the issues raised by the defendants' witnesses in the 19771978 trial and later cited by the Massachusetts Attorney General were referred to in the PF in the second criterion of the regulations and dealt with substantially continuous community.

The petitioners' researcher Christine Grabowski asserted that not only were the criteria for evaluating the tribal continuity deliberately and appropriately distinct in the administrative procedure from those used in the trial, but the evidence and its analysis were also different, allowing for a more extensive and thorough evaluation of tribal identity function and continuity (Bureau of Indian Affairs 2007: 13).

During the trial, sociologist Jean Guillemin claimed that she found no evidence of economic autonomy in the sense of communal or kin-based economic activities among the Mashpee. To her mind, "economic autonomy" meant some "degree of separate organization based on the principle of kinship, having to do with distribution of resources and labor" (Bureau of Indian Affairs 2007: 14). Rather than being economically autonomous, she contended, the Mashpee were part of the "market economy" and homeowners and, thus, economically assimilated. Therefore, she maintained that the Mashpee were not an Indian tribe in 1977.

The acknowledgement regulations, on the other hand, do not require a group to be "economically autonomous" from the wider society in order to demonstrate community (Bureau of Indian Affairs 1994). The Mashpee did not have to show a significant degree of shared or cooperative labor or other economic activity among the membership to prove community. 
The regulations do not bar acknowledgement of groups whose members participate in mainstream economic practices such as home ownership. They require a distinct community, not an isolated one.

Guillemin also argued that applications for federal funding of some Mashpee educational programs, designed to teach cultural traditions and native language to Mashpee children, showed a lack of distinctive culture for the group. In contrast, under the acknowledgement regulations participation in, and support for these programs, was seen as evidence of community. In any case, cultural distinctiveness is not required to be an Indian tribe or community. Rather, what is required is social distinctness within the wider society (Bureau of Indian Affairs 1994). It is enough to be a socially distinct group without having a separate culture.

In his testimony, historian Francis Hutchins claimed the Mashpee were not an Indian tribe in the years at any time between 1666 and $1970 .{ }^{4}$ In his opinion, an Indian tribe was "an entity composed of persons of American Indian descent, which entity possesses distinct political, legal, cultural attributes, which attributes have descended directly from aboriginal precursors" (Bureau of Indian Affairs 2007: 15). Not having accounted for cultural change, adaptation, and the effects of non-Indian society, Hutchins asserted that the Mashpee were not an Indian tribe historically because they adopted Christianity and non-Indian forms of dress and appearance, and chose to remain in Massachusetts as second-class citizens rather than emigrate westward to resume tribal existence. He also noted that they intermarried with non-Indians creating a "non-white" community. Hutchins thus required unchanged culture, including the maintenance of a traditional religion and essentially total social autonomy from non-Indian society.

In contrast to Hutchins' reasoning, under the acknowledgement regulations, these aspects of acculturation are compatible with the existence of a community for a group with significant social interactions and relationships (Bureau of Indian Affairs 1994). As long as the Mashpee continued to maintain a distinct social and political community, acculturation did not prevent them from demonstrating community. The Mashpee, in fact, used mainstream institutions like the Baptist Church and the town government to maintain community, and to foster social interaction and relationships among their members. What is more, they have managed to remain distinct from non-Indian populations in the surrounding area.

\footnotetext{
${ }^{4}$ Note that the court in its instructions did not ask the jury to determine tribal existence before 1790 .
} 
The continuous struggle for land...

Furthermore, the regulations do not view marriage with non-Indians as evidence that a group does not exist as a community. As long as Indian spouses and their children maintained interaction with the Indian community, marriage outside the group is not a problem in meeting the regulations. The Mashpee maintained significant kinship ties, social interaction, and historically concentrated residence patterns in and around the town of Mashpee.

In short, neither the comments of the Massachusetts Attorney General nor the evidence in the trial transcript it referenced changed the PF's conclusions that the Mashpee continuously constituted a distinct community. It was precisely the failure to prove the continuity of their community that made the Mashpee lose the 1977-1978 trial. Although continuity still remained an assumption under the federal regulations, it acquired a new, more inclusive meaning. Under the new regulations, the Mashpee only had to prove that they lived in a defined geographical area, composed mainly of their members.

\section{Contesting political influence or authority (criterion 3)}

The other part of the concerns of the Massachusetts Attorney General dealt with issues related to the third criterion of the regulations - maintaining political influence or authority over members.

During the 1977-1978 trial, Jean Guillemin claimed that the Mashpee were not politically autonomous or independent, "as distinct from the state, as distinct from let's say, a more rational political organization such as the township" (Bureau of Indian Affairs 2007: 20). She explained that the group lacked political autonomy because its members were politically assimilated and participated in state and local elections, and the dominant society did not recognize its leaders.

The acknowledgement regulations, on the other hand, define political autonomy as the exercise of political influence over a group's members on issues considered by them to be significant and as independent of any other federally recognized Indian governing entity (Bureau of Indian Affairs 1994). The Mashpee did not have to prove that they were politically independent in all ways from federal, state, and local governments. They could at the same time participate in the political process of the wider society and that of their own community. 
Referring to her concept of political autonomy, Guillemin also testified that she knew of no leaders in the Mashpee community who at any time had the power to make decisions affecting people's lives. The Mashpee PF, on the other hand, found evidence of political influence wielded by a long line of Mashpee leaders. Since the colonial era, the Mashpee have had sachems, proprietors, ministers and spiritual leaders, informal male and female leaders, elected and appointed district and town officials, and council members who have influenced and have been influenced by the members on important political matters (Bureau of Indian Affairs 2007: 21). Moreover, since the 1970s, the Mashpee leadership, formal and informal, played a key role in dealing with controversies involving outside groups, including the land claim suit, establishing community programs, defending the herring and shell fishing rights and beachfront access, and resolving internal conflicts among the members. Furthermore, it was demonstrated that the group members held these issues as important and they were highly engaged in the political processes (Bureau of Indian Affairs 2007: 21).

In addition, Gullemin testified that the leadership of Earl Mills, then chief of the group since the 1950s, was largely symbolic or ceremonial, and therefore did not constitute a leadership role (Bureau of Indian Affairs 2007: 21). The Mashpee did admit that the role of contemporary chief for the group, a position created in 1928 and elected by consensus members' vote, was largely, although not only, ceremonial. The chief, along with the medicine man, took care of cultural and social matters, and functioned as a ceremonial leader for outsiders. Despite the fact that the position lacked the legal authority of the incorporated council, it did command respect from and influence over the group. The chief also had a permanent voting seat on the Board of Directors, in existence since 1974. Hence, the chief did exert some political influence. Moreover, Earl Mills engaged in political activities that were not only ceremonial. For instance, in the $1950 \mathrm{~s}$ and 1960s he spent considerable time raising money and organizing the effort to restore the group's Old Indian Meeting House. In any case, the chief's position constituted only one small component of the group's multifaceted political structure since the 1970s (Bureau of Indian Affairs 2007: 21-22).

According to Francis Hutchins' testimony, the Mashpee were not an Indian tribe, which he defined "as an entity composed of persons of American Indian descent, which... possesses distinct political, legal, cultural 
The continuous struggle for land...

attributes, which... have descended directly from aboriginal precursors" (Bureau of Indian Affairs 2007: 22). By distinct political attributes, he meant:

an entity, group of persons, which has a structure of decision making, which has leadership, which is acknowledged, which is recognized by members of the group, so that decisions be arrived at which will be acknowledged by members of the group to be binding on them (Bureau of Indian Affairs 2007: 22).

At first glance, this definition might seem to reflect the requirement for political authority in the criterion. However, his idea of political influence drew upon the treaty making process of the $19^{\text {th }}$ century between the Indian tribes and the federal government, a more restrictive and limited notion of governmental control than in the regulations.

Previous acknowledgement findings have interpreted the regulations as requiring political influence that consists of a reciprocal relationship between the leaders and followers (Bureau of Indian Affairs 1994). The multifaceted political processes in Mashpee before the 1970s consisted of sachems, proprietors, ministers and spiritual leaders, informal male and female leaders, and elected and appointed district and town officials. After 1970, the group had an incorporated council, a traditional "elders" council, and "informal leadership that dealt with matters of consequence to the members. The members in turn understood, criticized, and participated in the political activities of their leaders" (Bureau of Indian Affairs 2007: 22-23).

The distinct legal attributes were understood by Hutchins as "something distinctive about the way in which [a] group organizes its internal affairs, arrives at decisions, enforces preferences within the group, that these procedures are different in some way from those which are followed by the ordinary citizens of the United States" (Bureau of Indian Affairs 2007: 23). As mentioned before, the regulations do not require a political structure or procedures which are unique or different in some way from that of the wider society. The Mashpee only had to prove that their leaders were capable of exerting significant influence over their followers and vice versa.

Therefore, the reevaluation of the evidence in the transcript, referenced in the Massachusetts Attorney General's comments, resulted in no changes in the PF's conclusions (Bureau of Indian Affairs 2007: 23). Moreover, the reconsideration of political authority in Mashpee clearly shows that the 
dichotomy of inclusion - exclusion, which was central to the 1977-1978 trial, no longer applied under the federal regulations. Embracing American political and legal institutions was no longer seen as giving up tribal political integrity. DOI's decision to recognize the Mashpee as a tribe marked a shift in the perspective of Native American identity, culture and history in the US. The change is clearly demonstrated by the discrepancies between the recognition criteria used in the 1977-1978 trial, and the criteria under the federal regulations used in 2007. The latter account for many of the aspects of political negotiation, cultural innovation and renewal that were dismissed by the jury thirty years earlier. As demonstrated above, the criteria of community continuity and political authority in particular illustrate this change.

\section{The results of the acknowledgement}

The decision granting the Mashpee tribe a government-to-government relationship with the United States was long-anticipated. Federal recognition was not only a matter of pride for the tribe but it was also the key to accessing millions of dollars in federal aid for housing, health care and education funds. Moreover, it paved the way for Mashpee to build casinos on tribal land under the 1988 Indian Gaming Act (Gonsalves 2007).

The tribe's sovereign-nation status became permanent 90 days after the decision was published in the Federal Register. Once this happened, the Mashpee Wampanoag became the 564th federally recognized tribe in the country, the second tribe to be granted sovereign-nation status in the state, and the first to be recognized under the Bush administration. BIA officials said the Mashpee petition was one of the strongest the agency had ever seen (Gonsalves 2007).

He adamantly confirmed that the 1977-1978 Mashpee land suit would not be reopened and that the tribe has no interest in taking privately owned land (Vosk 2007). However, he said that the tribe was interested in purchasing privately held land and petitioning the federal government for federal lands. They were particularly interested in property off-Cape for a tribal office to meet the needs of tribe members who lived elsewhere in the state, and possibly to build a resort casino (Gonsalves 2007).

As for the tribe itself, no noticeable changes in tribal governance were foreseen. Mashpee Selectman John Cahalane, who served on the town's 
The continuous struggle for land...

subcommittee on tribal affairs, said he looked forward to a mutually beneficial relationship between the town and tribe (Gonsalves 2007). Indeed, on April 22, 2008, an intergovernmental agreement between the town of Mashpee and the Mashpee Wampanoag tribe was signed. Under the agreement, the town agreed to help the tribe put 140 acres in town into trust with the federal government in exchange for a promise that the tribe will not build a casino or seek private or town-owned land in Mashpee (Vosk 2008). Stamping the agreement also made the tribe the official owner of several properties in town, including the Old Indian Meeting House. The tribe was also seeking 539 acres in Middleboro for a casino as part of its federal land trust application.

Recognition gave the Mashpee Wampanoag tribe many financial and legal benefits. Undoubtedly, the tribal members were proud and pleased to have won a legal battle that had lasted over thirty years. Moreover, in 2015, the Secretary of the Interior was able to take the tribe's land into trust, which granted them a reservation. Since then, the tribe has developed housing, healthcare, its own police department, a tribal court, and a school that teaches the Wampanoag language. In January 2016, the DOI placed another tract of land in nearby Taunton in Mashpee's trust to be developed as a "commercial/industrial park" that would include a casino (McDougall and Cannon 2020).

However, in February 2016, a group of 24 local residents led by Michelle and David Littlefield took the tribe to court, claiming that the BIA had "exceeded its statutory authority" by putting the land in trust, as the Mashpee did not meet the definition of "Indian" under the Indian Reorganization Act of 1934 (IRA) as interpreted by the 2008 Supreme Court Case Carcieri v. Salazar. ${ }^{5}$ On July 28, 2016, the United States District Court for the District of Massachusetts remanded the case to DOI to consider whether the Mashpee Wampanoag Tribe in fact met one or more of the definitions of "Indian" under the IRA (Secretary of the Interior 2018). On September 7, 2018, the Secretary of the Interior (head of DOI) came to the conclusion that the Mashpee did not fit the first definition, and thus DOI was wrong to have taken their land into trust in the first place:

${ }^{5}$ The 1934 Indian Reorganization Act, also known as the Wheeler-Howard Act, was intended to decrease federal control over Native tribes and allow them to largely selfgovern. The IRA “affirmed Native nations' sovereign control over their lands, allowed them to purchase new land using federal loans, and authorized the Secretary of the Interior to accept additional tribal lands into trust and proclaim new reservations on those lands" (McDougall and Cannon 2020). 
Based on my review and consideration of these submissions, I cannot conclude that the Tribe was "under Federal jurisdiction" in 1934. As a result, the Tribe does not satisfy the "under Federal jurisdiction" requirement of the first definition of "Indian," and it also does not satisfy such requirement with respect to the second definition as that definition has been interpreted by the United States District Court for the District of Massachusetts. (Secretary of the Interior 2018).

Still, it was not until March 2020, that the Secretary of the Interior, David Bernhardt, actually decided to take the Tribe's land out of trust. As a result, Mashpee took civil action against his decision in the case Mashpee Wampanoag Tribe v. Bernhardt.

Thus, Mashpee's 2008 legal victory was short lived. The U.S. has not taken land out of trust since the 1950s, and the consequences of doing so in March 2020 would have been devastating for the Mashpee Wampanoag Nation. Not only would the tribe no longer have sovereign control over the land (although they would still technically own it), but their government and social services would have to be dissolved. It would have also lost all protections against state mechanisms to acquire the land (Cannon and McDougall 2020).

Although, as mentioned in the introduction to this article, the United States District Court for the District of Columbia has reverted DOI's March 2020 decision, at least temporarily, it goes to show that land and tribal status could still be taken away from the Mashpee and other tribes (particularly those who gained tribal status after 1934, as will be explained below). New interpretations of the term "Indian" in existing legal documents are used by DOI to undermine tribal sovereignty and deprive Indigenous communities of their lands and the social and economic benefits that come with it.

\section{Recent land dispute}

There are several legal issues that have led to DOIs March 2020 decision to take Mashpee tribal land out of trust: the above-mentioned lengthy dispute with nearby residents to build a casino on a 150 -acre tract of reservation land in Taunton and the US Court of Appeals for the First Circuit's ruling in 2018 in favor of the residents, based on the 2009 Supreme Court 
The continuous struggle for land...

Case Caricieri v. Salazar; as well as the rescission of the 2014 Carcieri m-opinion and the issuance of a new m-opinion along with a 4-part test to qualify under the first definition of "Indian" in the Indian Reorganization Act (Mashpee Wampanoag Nation 2020a). I will attempt to describe these decisions and opinions and explain their implications for the Mashpee below.

\section{Caricieri v. Salazar 555 U.S. 379 (2009)}

Carcieri v. Salazar is a controversial case in which the Supreme Court ruled that the federal government could not take land into trust that was acquired by the Narragansett Tribe, which resides in Rhode Island, as it was not federally recognized before the Indian Reorganization Act of 1934 (Donald L. Carcieri, et al. v. Ken L. Salazar, et al., 555 U.S. 379). In the Court's opinion, the phrase tribes "now under Federal jurisdiction" in the IRA referred only to those tribes that were federally recognized when the act was passed (Wheeler-Howard Act of 1934, 48 Stat. 988). It ruled that the federal government could not take land into trust for the Narragansett or other tribes that were federally recognized and acquired land after 1934.

Before the 2009 case, U.S. Secretary of the Interior Ken L. Salazar granted 31 acres of trust land to the Narragansett Tribe. Rhode Island Governor, Donald L. Carcieri, sued Salazar, claiming he did not have the authority to do so. Carcieri was concerned that the Narragansett would use the trust land to build a casino or another business that could not be taxed by the state of Rhode Island, although the tribe had purchased the 31 acres in 1991 in order to build a housing complex for the elderly. At the tribe's request, the Department of the Interior took those 31 acres into trust in 1998 (McDougall and Cannon 2020).

The Carcieri v. Salazar decision was criticized by both Native American and legal communities. The American Bar Association newsletter quickly pointed out possible adverse consequences for Indian gaming and tribal sovereignty, as many tribes, including the Mashpee, have achieved federal recognition only in the latter part of the $20^{\text {th }}$ century, as a result of activism. For instance, USET SPF has argued that the case has created: 
(...) a deeply inequitable 2-class system, in which some Tribal Nations have the ability to restore their homelands and others do not. This 2-class system serves to deny these Tribal Nations a critical component of the trust relationship, vital aspects of the exercise of inherent sovereignty, and the opportunity to qualify for several government programs (USET SPF 2020).

Tribal Nations have also attempted to reverse the Caricieri v. Salazar decision by garnering the support of congressmen and taking congressional legislative action that would allow the BIA to continue taking tribal lands into trust.

Fortunately, Native American Tribal Nations have been able to avoid the devastating effects of the Caricieri v. Salazar decision thanks to a 2014 Department of the Interior Solicitor's m-opinion, M-37029 “The Meaning of 'Under Federal Jurisdiction' for Purposes of the Indian Reorganization Act," that offers "a measured and consistent interpretation" of the phrase "under federal jurisdiction" and has allowed for "the continued acquisition of trust lands for Tribal Nations" (Mashpee Wampanoag Nation 2020a; USET SPF 2020). ${ }^{6}$

However, on March 10, 2020, the Department of the Interior officially withdrew M-37029, and simultaneously issued a new m-opinion, M-37055, which "alleges that M-37029 is not consistent with the intent of the Indian Reorganization Act (IRA) and announces the implementation of new procedures to be used in determining whether Tribal Nations meet the definition of 'under federal jurisdiction' for the purposes of the IRA" (USET SPF 2020). The new procedures establish a new 4-part test, which is still under evaluation by USET SPF. The organization is concerned that the new 4-part test "could serve to disrupt and restrict trust land acquisition" (USET SPF 2020).

The new procedures were not consulted with USET SPF, NCAI nor Tribal Nations which, according to USET SPF, shows the Trump administration's intention to serve those outside of Indian Country. "The bottom line", it says, "is that through this action, DOI has failed to uphold numerous aspects of trust and treaty obligations to Tribal Nations, including consultation, the restoration of Tribal homelands, and the promotion of

${ }^{6}$ Department of Interior Solicitor's m-opinions do not have the force and effect of law and are not meant to bind the public in any way. These documents are intended only to provide clarity to the public regarding existing requirements under the law or agency policies (https://www.doi.gov/solicitor/opinions). 
The continuous struggle for land...

Tribal sovereignty" (USET SPF 2020). DOI's March $26^{\text {th }}$ decision to take the Mashpee Wampanoag Nation's land out of trust thus came a couple of weeks after the new m-opinion M-37055 was issued, and the Mashpee, like other Tribal Nations, had not yet responded to it.

Luckily for the tribe, on June $5^{\text {th }}$, 2020, the United States District Court for the District of Columbia rendered a decision in its favor in the case Mashpee Wampanoag Tribe v. Bernhardt, asking DOI to reexamine its decision to take the tribe's more than 300 acres of land out of trust. Not only did it call DOI's 2018 decision that the Mashpee Wampanoag Tribe did not meet the first definition of "Indian" under the IRA arbitrary and capricious, but it also remanded the decision to DOI "with clear direction to issue a decision consistent with the 2014 m-opinion's standard", thus preventing it from applying its new 4-part test in this case (Mashpee Wampanoag Nation 2020a). "The Court further directed DOI to properly address each piece of evidence, give a reasoned analysis as to whether it is probative, explain any departure from past DOI precedent, and view all probative evidence in concert rather than in isolation" (Mashpee Wampanoag Nation 2020a). This is particularly important, because, as stated by the Tribe's attorney, Tami Azorsky, during a May 2020 hearing in the case, the Court had dismissed each piece of evidence individually, while "when viewed in context and that together they are the types of evidence that in other cases the Secretary determined the tribe was 'under federal jurisdiction"" (Kickingwoman 2020).

What is also important is that the Court's decision guarantees that DOI maintain the land in trust pending DOI's new determination and prevents it from applying the new 4-part test (Mashpee Wampanoag Nation 2020a). However, the Mashpee still await a positive determination on their homelands. Tribal Chairman, Cedric Cromwell stated:

While we are pleased with the court's findings, our work is not done. The Department of Interior must now draft a positive decision for our land as instructed by Judge Friedman. We will continue to work with the Department of the Interior and fight them if necessary — to ensure our land remains in trust (Kickingwoman 2020).

Unfortunately, the Secretary of the Interior decided to appeal the ruling. It thus remains to be seen what the outcome of the case for the Mashpee will be. 


\section{Congressional legislative action}

Simultaneously, the Mashpee have also managed to get congressional support for their case. On May 20, 2020, a bicameral, bipartisan amicus brief addressing the Mashpee Wampanoag Tribe v. United States Department of the Interior was filed by Congresswoman Deb Haaland (a Laguna Pueblo citizen and a Democrat from the State of New Mexico) and Joe Kennedy III (a Democrat from Massachusetts) "against unprecedented action to remove Mashpee Wampanoag Tribe's land from tribal trust status" (Kennedy III 2020a). The brief was signed by 25 members of Congress. It "argues that the Executive Branch infringed on the powers of Congress by attempting to exert unlawful authority over Indian tribes without a Congressional directive to take the Tribe's land out of trust, especially during a national emergency" (Kennedy III 2020a). The congresspeople emphasized that: "When it comes to Indian lands, congressional power is at its apex and the Executive Branch is forbidden to disturb tribal lands unless Congress has directed or permitted it in clear and unambiguous terms" (Kennedy III 2020a).

Apart from the amicus brief filed in May 2020, mentioned above, several bills were introduced in the House of Representatives, whose aim is to protect Mashpee and other tribal lands. One of Mashpee's major allies in the House of Representatives has been Congressman Joe Kennedy III. In January 2019, together with Congressman Bill Keating (also a Democrat from Massachusetts), he introduced a bipartisan bill, The Mashpee Wampanoag Tribe Reservation Reaffirmation Act (HR 312), which would reaffirm the Tribe's legal and historical claims to the land (Kennedy III 2020b). The bill was coined in response to DOI's September 2018 decision that opened the door for the Tribe's land to be taken out of trust. It was passed in the House in May 2019, but has only been taken up by the Senate recently. After DOI's March 2020 decision to actually take Mashpee's land out of trust, Congressman Joe Kennedy III issued a bipartisan letter to Senate Majority Leader Mitch McConnell, demanding an immediate voice vote on the bill. He highlighted its urgency:

Injustice for indigenous communities carries an ever-darkening cloud over our nation's pursuit for equality and justice. Instead of righting the wrongs of our past, the Trump Administration's decision to disestablish the Mashpee Wampanoag tribal lands ignores precedent and our country's history. Now the choice lies in the 
The continuous struggle for land...

hands of Mitch McConnell and the United States Senate: either protect the Mashpee Wampanoag people or become complicit in the President's disregard for the humanity and dignity of indigenous Americans (Kennedy III 2020b).

As I am writing this article, the bill has undergone a second Senate reading, yet still awaits a Senate vote.

In the meantime, Congresswoman Deb Haaland, together with Congressman Joe Kennedy III introduced the Tribal Reservation Pandemic Protection Act on June 11, 2020. It would prohibit the Trump Administration from threatening tribal reservation lands in general (not just those of the Mashpee Wampanoag Tribe) amidst the COVID-19 pandemic (Kennedy III 2020c). The congressmen asserted:

Even after the recent court victory for the Mashpee Wampanoag Tribe, the potential of a lengthy appeals process threatens the sovereignty and survival of the tribe. As the Department of Interior considers further dangerous actions against the Mashpee Wampanoag people, this legislation would give the tribe certainty and would ensure no other tribe in the country would face similar attacks (Kennedy III 2020c).

However, the bill still awaits a vote in the House of Representatives, and then consideration by the Senate.

Fortunately for the Tribe, on 24 July 2020, another congressional piece of legislation was passed in the U.S. House of Representatives that might finally put an end to any disputes over Mashpee lands. Namely, the House passed a package of appropriations bills, H.R. 7608, that, among other provisions, includes an amendment that protects the land of the Mashpee Wampanoag Tribe (Mashpee Wampanoag Nation 2020b). The bill provides funding for a variety of federal agencies. The particular amendment that deals with Mashpee lands was introduced by Congressman Joe Kennedy III and Congressman Bill Keating and signed by Congresswoman Deb Haaland and Congresswoman Lori Trahan. The language of the document "prevents the Interior Department from taking any action that would dispose of the Tribe's land and reservation. It would also protect the Mashpee Wampanoag Tribe from endless litigation and fully recognize their tribal lands without interference from the federal government" (Mashpee Wampanoag Nation 2020b). The legislation is now going to be considered by the Senate. 
In sum, the future of Mashpee tribal lands remains to be decided. DOI still needs to respond to the Federal District Court's instructions to issue a decision consistent with the 2014 m-opinion's standard and properly assess all of the evidence in the case Mashpee Wampanoag Tribe v. Bernhardt, although the recent appeal by DOI indicates that the Secretary of the Interior is not going to give up without a fight. Moreover, the congressional support for the tribe received from the House of Representatives is encouraging, yet the particular bills introduced still await consideration and/or vote by the House itself or the Senate. They later need to be signed into law by the President of the United States. Thus, it is likely that their implementation will depend on the results of the November 2020 presidential elections, given how unfavorable President Trump's administration has been toward the Mashpee and other Tribal Nations so far.

\section{Conclusion}

Between court cases, DOI decisions, Solicitor General's m-opinions and congressional legislative action, there are many avenues for the local community, state, and federal government to interfere with Mashpee's sovereignty rights and, on the other hand, for the Mashpee to fight back at these attempts. As much as general attitudes toward Indigenous land rights and sovereignty might have changed in the latter part of the $20^{\text {th }}$ century, and as much as this has been reflected in the law, i.e., in the criteria for federal recognition in the Code of Federal Regulations (compared to the criteria used in the Mashpee 1977-1978 trial), where ossified notions of tradition and culture are no longer used, and acculturation is no longer seen as rejecting tribal identity, the current legal actions on the part of the state and federal governments show that the Mashpee and other tribal nations cannot be sure of the future of their tribal status. Although initially allowed by the 2009 Caricieri v. Salazar Supreme Court decision, it is primarily the action taken by the current administration, represented by Secretary of the Interior, David Bernhardt, which undermines tribal sovereignty. Trying to take Mashpee's land out of trust, reverting previous legal documents in support of Tribal Nations (Solicitor General's m-opinion in the matter), and not consulting Indigenous legal institutions and tribal governments in the process make the administration's intentions clear. Unfortunately, just like in the case of the Narragansett tribe, the 
undermining of Mashpee's sovereignty primarily has to do with the state wanting financial benefits from its gaming operations. Suffice it to say that one of the plaintiffs in the 2016 court case against the Mashpee concerning the land in Taunton, Frances Lagace, had wanted to open up Taunton to commercial casino license applications in the state, and the Mashpee casino clearly stood in their way (Cannon and McDougall 2020). The trial also proves that the local community only wants to allow Mashpee sovereignty to the extent that it does not interfere with their vision of how the land in Taunton should be used, or who should benefit from it financially.

These recent events clearly show that the granting of federally recognized tribal status to tribal nations in the United States is only partially a result of accepting their perspective of history by the settler government. Rather, it is a result of tribal nations' stubborn fight for and negotiation of their sovereignty and land rights. As clearly exemplified by the lengthy and difficult struggle of the Mashpee tribe, despite the positive changes in the law, the government is still able to find or even create legal instruments to undermine that status, fueled by financial incentives for the state.

\section{REFERENCES:}

Bureau of Indian Affairs (1994). 25 Code of Federal Regulations, Part 83-Procedures for establishing that an American Indian group exists as an Indian tribe. Final Rule. Obtained from https://www.bia.gov/sites/bia.gov/files/assets/as-ia/ofa/admindocs/25CFRPart83_1994_FinalRule.pdf

Bureau of Indian Affairs (2007). Summary under the criteria and evidence for final determination for federal acknowledgement of the Mashpee Wampanoag Tribal Council Inc. Obtained from https://www.bia.gov/sites/bia.gov/ files/assets/as-ia/ofa/petition/015_mashpe_MA/015_fd.pdf

Cape Cod Times (2002) Mashpee Wampanoag: A history. Cape Cod Times. Retrieved May

12, 2008. Obtained from http://archive.capecodonline.com/special/tribalrecog/ tribal16side.htm

Clifford, J. (1988). The predicament of culture: Twentieth-century ethnography, literature, and art. Cambridge, Mass.: Harvard University Press. DOI: 10.2307/j.ctvjf9x0h

Deloria, Jr.V., Lytle, C.M. (1983). American Indians, American justice. Austin: University of Texas Press. 
Donald L. Carcieri, et al. v. Ken L. Salazar, et al., 555 U.S. 379 (2009). Obtained from https://caselaw.findlaw.com/us-supreme-court/555/379.html

Gonsalves, S. (2007, February 16). A nation reborn. Cape Cod Times. Retrieved May 18, 2008. Obtained from http://archive.capecodonline.com/special/tribalrecog/anation $16 . \mathrm{htm}$

Jungreis, M. (2020, March 28). Mashpee Wampanoag Tribe is losing its reservation. The

Boston Globe. Obtained from https://www.bostonglobe.com/2020/03/28/metro/ mashpee-wampanoag-tribe-is-losing-its-reservation-leader-says/

Kennedy III, J. (2020a). Kennedy, Haaland file bicameral, bipartisan legal brief to protect

Mashpee Wampanoag land. Obtained from https://kennedy.house.gov/newsroom/press-releases/kennedy-haaland-file-bicameral-bipartisan-legal-briefto-protect-mashpee-wampanoag-land

Kennedy III, J. (2020b). Kennedy to Senate: Act now to protect Mashpee Wampanoag

Tribe. Obtained from https://kennedy.house.gov/newsroom/press-releases/ kennedy-to-senate-act-now-to-protect-mashpee-wampanoag-tribe

Kennedy III, J. (2020c). Kennedy, Haaland intro bill to protect tribal lands during covid-19

pandemic. Obtained from https://kennedy.house.gov/newsroom/press-releases/kennedy-haaland-intro-bill-to-protect-tribal-lands-during-covid-19pandemic

Kickingwoman, K. (2020, June 6). Mashpee Wampanoag: US court 'stood up for justice'.

Indian Country Today. Obtained from https://indiancountrytoday.com/news/ mashpee-wampanoag-us-court-stood-up-for-justice-HhCupRHu4Eid$1 \mathrm{Alpq} 2 \mathrm{zUA}$

Mashpee Wampanoag Nation. (2020a). Federal Court Rules in Favor of Mashpee

Wampanoag Nation. Mittark. Obtained from https://mashpeewampanoagtribe-nsn.gov/july-2020-mittark-feature-court

Mashpee Wampanoag Nation. (2020b). Mashpee Wampanoag Tribe Applauds Legislation

Passed by U.S. House to Protect Land. Mittark. Obtained from https://mashpeewampanoagtribe-nsn.gov/news/2020/7/24/mashpee-wampanoag-tribe-applauds-legislation-passed-by-us-house-to-protect-land?fbclid=IwA R19kwLAEr5ypB1ZqDfE8bNUmDtqXyMjQurGlGxCTXaRzSEsihZkB $\mathrm{Vb}-\mathrm{K} 1 \mathrm{Q}$ 
Mass Moments. (n.d.). Mashpee Indians sue for recognition. Mass Moments. Obtained from https://www.massmoments.org/moment-details/mashpee-indians-sue-for-recognition.html

Mashpee Tribe, Plaintiff, Appellant, v. New Seabury Corp. et al. (1979). US Court of Appeals cases and opinions. Obtained from http://cases.justia.com/ us-court-of-appeals/F2/592/575/

Montoya v. United States. (1901). https://law.resource.org/pub/us/case/reporter/ F3/386/386.F3d.1271.02-17239.html

O’Brien, Sh. (2007). Native American Policy, in Microsoft Encarta Online Encyclopedia. Retrieved April 29, 2008. Obtained from http://encarta.msn. com

USET SPF (2020). USET SPF Alert: DOI Withdraws 2014 M-Opinion Providing 2-Part

Carcieri Test, Implements New 4-Part Test. Obtained from https://www.usetinc. org/wp-content/uploads/2020/03/March11USET-SPF-AlertDOI-Withdraws-2014-M-Opinion.pdf

Vizenor, G. (1994). Manifest Manners: Narratives on Postindian Survivance. Lincoln:

University of Nebraska Press.

Vosk, S. (2007). 'We're not going to go second best' on casino. Cape Cod Times. Retrieved 12 May, 2008. Obtained from http://archive.capecodonline.com/ special/tribalrecog/xwexrenot16.htm

Wheeler-Howard Act of 1934, 48 Stat. 988. (2020). Obtained from http://aghca. org/wp-content/uploads/2012/07/indianreorganizationact.pdf 